\title{
Enthusiastic discussions on solid physic and material science at SPMS2019
}

\author{
Van-Duong Dao ${ }^{1,2, *}$, Nguyen Duc Chien ${ }^{3}$, Wiesław Strek ${ }^{4}$
}

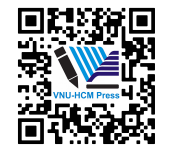

Use your smartphone to scan this QR code and download this article

${ }^{1}$ Faculty of Biotechnology, Chemistry and Environmental Engineering, Phenikaa University, Hanoi 10000, Vietnam

${ }^{2}$ Phenikaa Research and Technology Institute (PRATI), A\&A Green Phoenix Group, 167 Hoang Ngan, Hanoi 10000, Viet Nam

${ }^{3}$ International Training Institute for Materials Science (ITIMS), Hanoi University of Science and Technology (HUST), No 1 - Dai Co Viet Str, Hanoi, Vietnam

${ }^{4}$ Institute of Low Temperature and Structure Research, Polish Academy of Sciences, Wroclaw, Poland

\section{Correspondence}

Van-Duong Dao, Faculty of Biotechnology, Chemistry and Environmental Engineering, Phenikaa University, Hanoi 10000, Vietnam

Phenikaa Research and Technology Institute (PRATI), A\&A Green Phoenix Group, 167 Hoang Ngan, Hanoi 10000, Viet Nam

Email:

duong.daovan@phenikaa-uni.edu.vn

History

- Received: 2020-03-19

- Accepted: 2020-04-03

- Published: 2020-04-09

DOI : 10.32508/stdj.v23i2.1768

\section{Check for updates}

\section{Copyright}

(c) VNU-HCM Press. This is an openaccess article distributed under the terms of the Creative Commons Attribution 4.0 International license.

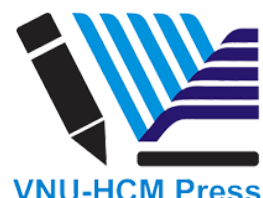

\begin{abstract}
At $11^{\text {th }}$ National Conference of Solid Physics and Material Science (SPMS2019), to which eminent scientists (5 plenary speakers and 16 invited speakers) were invited, most of the discussion focused on solid physic and material science. Around 300 researchers interested in the subject attended the conference and actively participated in the discussion. There were more than 200 reports with five specialized subcommittees: (A) Physics and magnetic materials, (B) Semiconductor and dielectric physics, (C) Materials - semiconductor components - dielectric, (D) Biomedical materials - agriculture, energy - environment, (E) Composite materials - metals - ceramics. Besides, numerous reports submitted to the Journal of Science and Technology (Vietnam Academy of Science and Technology), full-text reports sent to the Organizing Committee, after a critical review process, had been summarized and published in the Collection of conference reports.
\end{abstract}

Key words: Solid physic, Materials Science, SPMS, Energy conversion, Carbon Materials

\section{INTRODUCTION}

SPMS2019 co-organized by the Vietnam Physical Society, the Vietnam Materials Research Society, the Institute of Physics, the Institute of Materials Science (Vietnam Academy of Science and Technology), Vietnam National University (VNU), Phenikaa University and Quy Nhon University was held on 2 - 4 November, 2019 in Quy Nhon City, Binh Dinh Province. The conference has been attracted 5 pleanary speakers, 16 invited speakers and around 300 researchers (Figure 1, Table 1 and Table 2). It is not only a large and prestigious scientific forum, attracting the attention of the Vietnamese scientific community but also a place to meet, exchange, and disseminate the latest developments in the field of SPMS. It was held every two years continuously from 1995. Generally, solid physics and material science fields are always concerned topic of many scientists, which has diverse activities and outstanding achievements in both fundamentals and applications in Vietnam.

SPMS-2019 is not only fundamental materials but also presents the application of the developed materials in energy conversion and storage device, photocatalysis, catalysis, health care, etc. To share research about graphene application, Prof. Strek, editor of Journal Alloys and Compounds, who has researched graphene fundamentals and applications for decades $^{1,2}$, gave a presentation on graphene for photonics and lighting as shown in Figure 2. In the presentation, the intensity of the emission surges expo- nentially with the rise of laser power density, saturating at ca. $1.5 \mathrm{~W}$ and being characterized by stable emission conditions. Furthermore, the white light emission is spatially confined to the focal point dimensions of the illuminating laser light. The emission intensity could be controlled owing to the extreme reliance on the white light emission on the electric field intensity. The electric field intensity at ca. $0.5 \mathrm{~V} / \mu \mathrm{m}$ was able to decline the white light intensity by approximately $50 \%$. This presentation concluded that the laser-induced white light emission might be well utilized in new types of white light sources. Given that the talk of Prof. Strek presented the fundamental materials which are based on carbon materials, Dr. Van-Duong Dao (Phenikaa University) presents the use of carbon materials in harvesting energy and fresh-water via solar-driven water evaporation system. Recent improvements and difficulties in applying a solar-driven water evaporation system were first presented (Figure 3$)^{3}$. The invited speaker also presented the recent development of dual dual-function nanogenerators that are based on a natural structure as Limnobium laevigatum, ferns, cone, etc. The developed nanogenerators made of multi-walled carbon nanotubes-coated cellulose paper in ponds, lakes, rivers, seas, etc. any time of a day could generate electricity and freshwater efficiently. It utilizes solar energy to produce fresh-water from any polluted or saline water source at a significant production rate and generates high 
electric power in the hundreds $\mathrm{mW} \cdot \mathrm{m}^{-2}$ range using the evaporation-enhanced capillary water stream of the structure under ambient daylight conditions. Because these nanogenerators acquire all required energy from the environment, it will find immediate applications in providing electricity and fresh-water for living and system maintenance in water-abundant isolated locations such as islands or wetlands. The findings of this work represent a significant step forward because they pointed out the concept of harvesting consistently electricity during evaporation the whole day and with any weather conditions ${ }^{4}$. Note that before presenting the harvesting fresh-water from a solar-driven water evaporation system, the invited speaker presented a new technology for synthesizing nanohybrid materials and their applications on next-generation solar cells, energy storage devices, solar to steam generation, and photocatalysis which is called dry plasma reduction ${ }^{5}$. Note that this technology can work under atmospheric pressure, low temperature, short time reduction, and without using any toxic chemical reagents (Figure 4). Several examples for fabricating transparent electrodes based on Pt nanoparticles on FTO glass substrate, $\mathrm{Pt} / \mathrm{CVD}$-grown graphene on FTO glass substrate, and $\mathrm{Pt}$-graphene/Ag nanowire on glass have been carefully described ${ }^{6,7}$.

The water harvesting issue is continued by a discussion of Prof. Phan Bach Thang (Center for Innovative Materials and Architectures (INOMAR), Vietnam National University, HoChiMinh city (VNUHCM)). As an oral presenter, the device based on a porous metal-organic framework MOF-801, $\left.\left.\left[\mathrm{Zr}_{6} \mathrm{O}_{4}(\mathrm{OH})_{4} \text { (fumarate) }\right)_{6}\right]\right\}$ can capture water from the atmosphere at ambient conditions by using low-grade heat from natural sunlight at a flux of less than one sun (1 kilowatt per square meter ${ }^{8}$. This system can harvest 2.8 liters of water per kilogram of MOF per day at relative humidity levels as low as $20 \%$ without additional input of energy (Figures $5 \mathrm{a}-\mathrm{c})^{8}$. A prototype using up to $1.2 \mathrm{~kg}$ of MOF-801 was tested in the laboratory and later in the desert of Arizona, USA. It generated $100 \mathrm{~g}$ of water per kilogram of MOF-801 per day-and-night cycle with only natural cooling and input energy, namely ambient sunlight ${ }^{9}$. Note that by using an aluminum-based MOF-303, the device can deliver more than twice the amount of water. The desert experiment uncovered key parameters of the energy, material, and air requirements for efficient production of water from desert air, even at a subzero dew point. Prof. Thang's center also synthesized a lot of MOF with the named VNU-number such as VNU-1, VNU-2, etc. and their application in energy, environment, catalysis, health care $^{10-17}$

Dr. Phong D. Tran (University of Science and Technology of Hanoi, Vietnam) described the current state-of-the-art of the solar water splitting research. The current progress in the development of noblemetal free catalysts ${ }^{18-22}$, nanostructured light harvesters $^{23,24}$, as well as the catalyst/light harvester assemblage for artificial leaf construction ${ }^{24}$, was also presented. Dr. Tran's group found that the operation of a bias-free leaf displaying $2 \%$ solar-to- $\mathrm{H}_{2}$ conversion yield in $\mathrm{pH} 7$ phosphate buffer solution and under 1 Sun illumination. Prof. Sunglae Cho (University of Ulsan, Korea) discussed the preparation of highquality single crystal and a thin film of 2-dimensional materials (2D) including SnSe, $\mathrm{SnSe}_{2}, \mathrm{InSe}, \mathrm{In}_{2} \mathrm{Se}_{3}$, and $(\mathrm{BSb})_{2}(\mathrm{SeTe})_{3}$, etc.

The oral presentations continued from Sunday to Monday afternoon. The coffee breaks and poster sections were filled with cozy discussions and networking. SPMS2019 was a fantastic meeting thanks to the participants from all over the world and the host who organized and prepared carefully for the conference. Especially, thanks are owed to the chairs of each conference day: Prof. Nguyen Duc Chien, Prof. Nguyen Dai Hung, Prof. Do Ngoc My, Prof. Le Quoc Minh, Prof. Nguyen Hoang Luong, and chair sections.

The conference hopes that all participants had fruitful experience and were motivated by many impressive ideas from SPMS2019. SPMS2021 will be held after the next two years. Based on the experience of the long history, the organization intends to organize a more valuable conference that has an additional section for abroad researchers. We hope that SPMS2021 will be a remarkable chance for many scientists who are interested in solid physic and materials science and their application. It would be a pleasure to meet again at SPMS2021. 


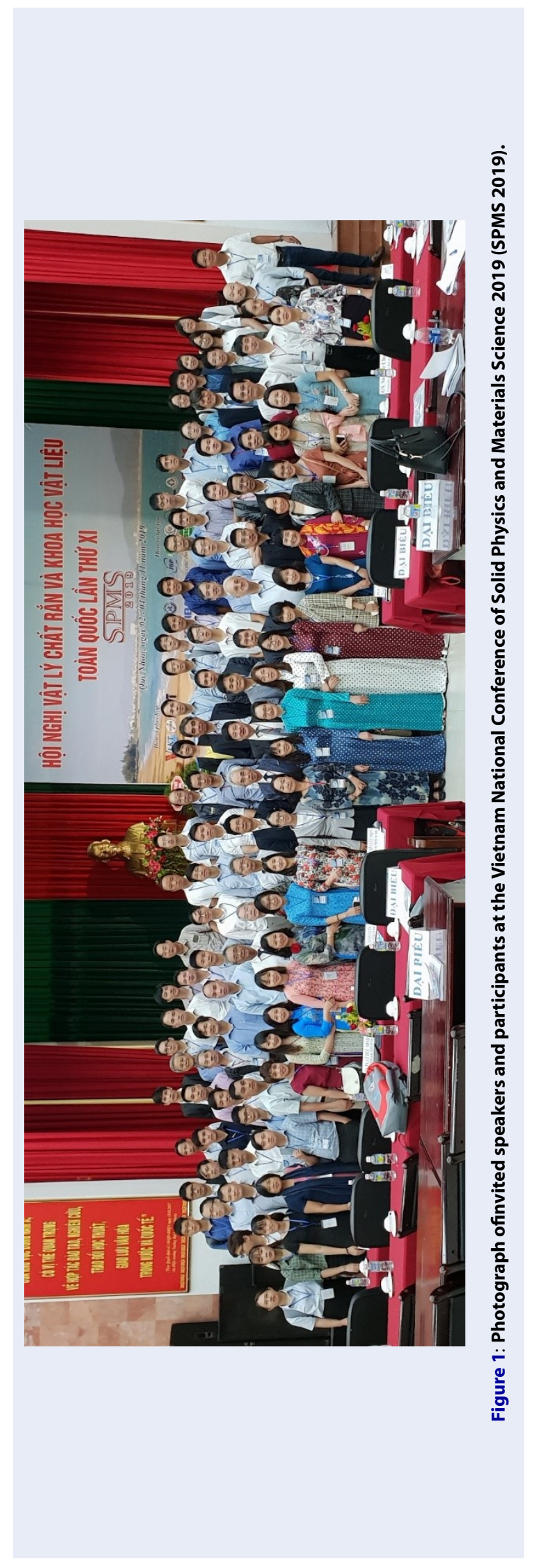



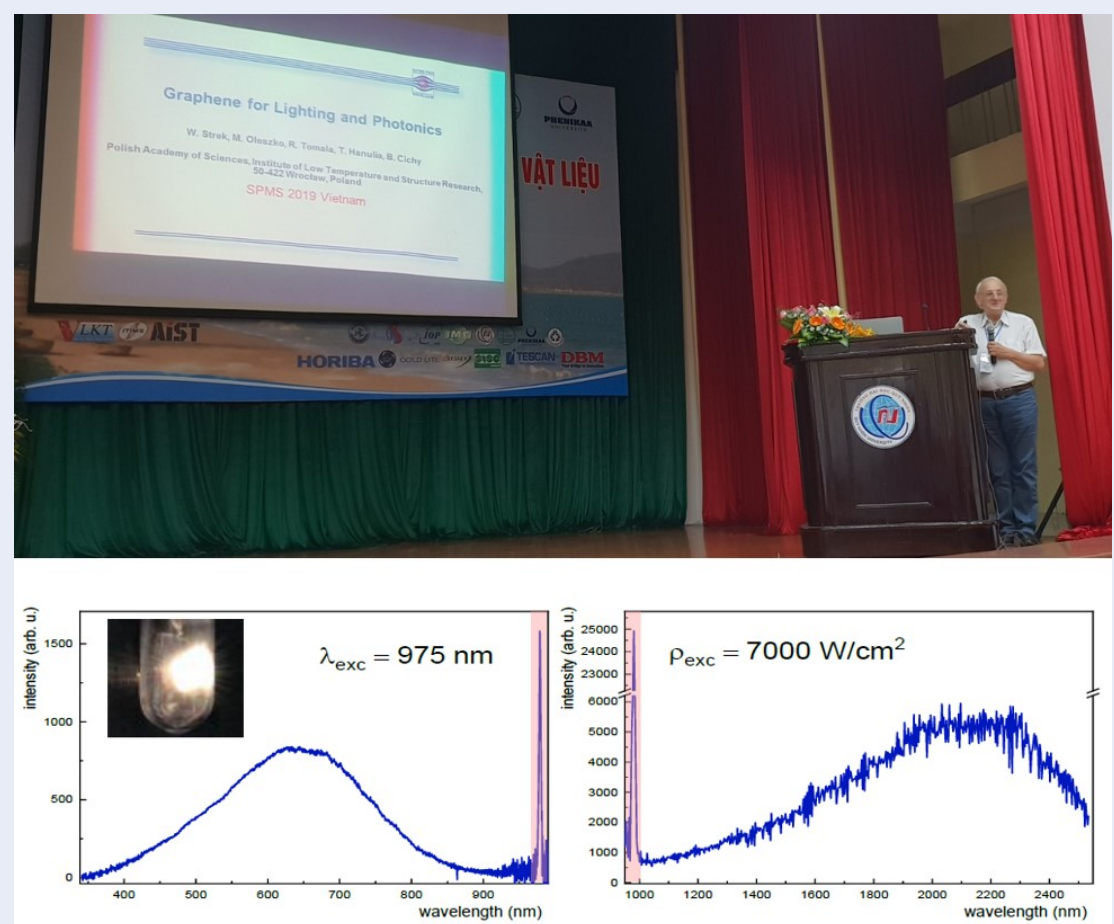

Figure 2: Prof. Strek giving talks to the conference; The visible and near-infrared emission of graphene foam excited by $975 \mathrm{~nm}$ laser diode at high excitation density $7000 \mathrm{~W} / \mathrm{cm}^{2} 2$.

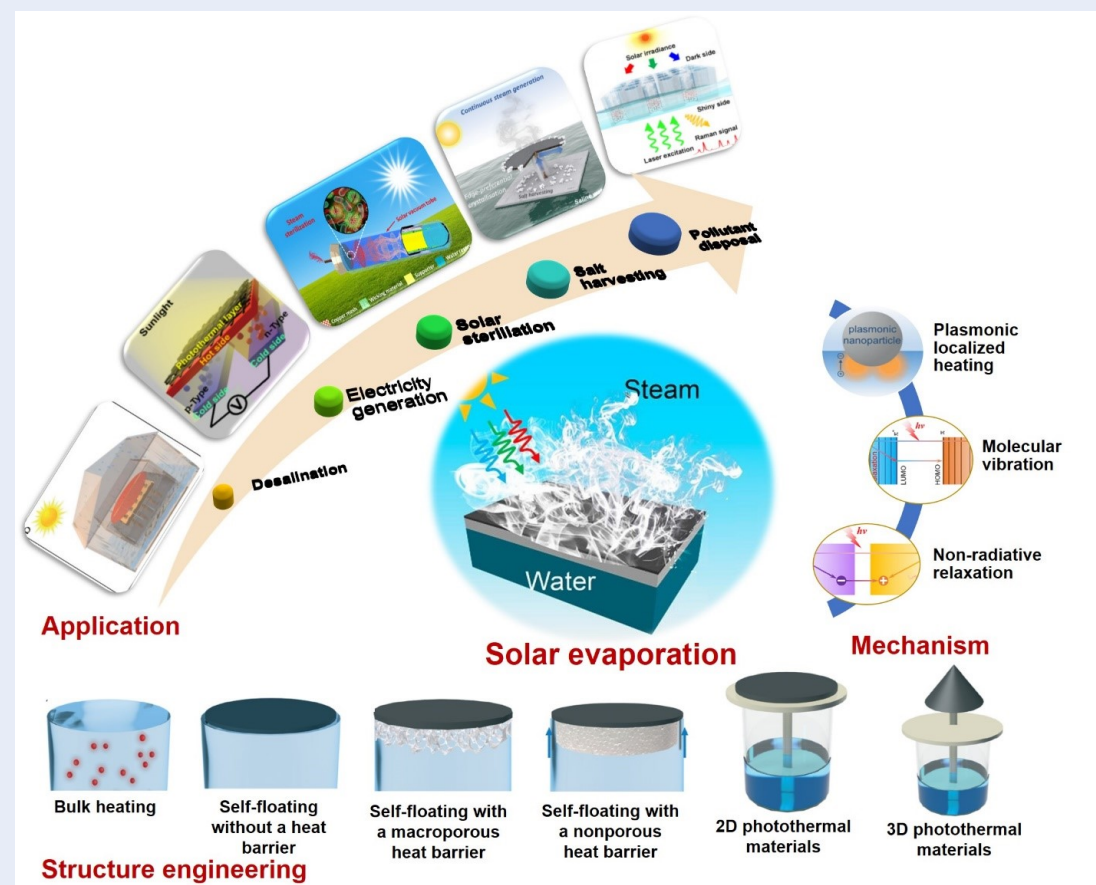

Figure 3: Schematic illumination of the development of solar-driven interfacial steam generation system ${ }^{3}$. 


\section{Nano scale Plasma-Surface interactions lead to reforming the GO and Metal- precursors into functional nano-material for Energy devices!}

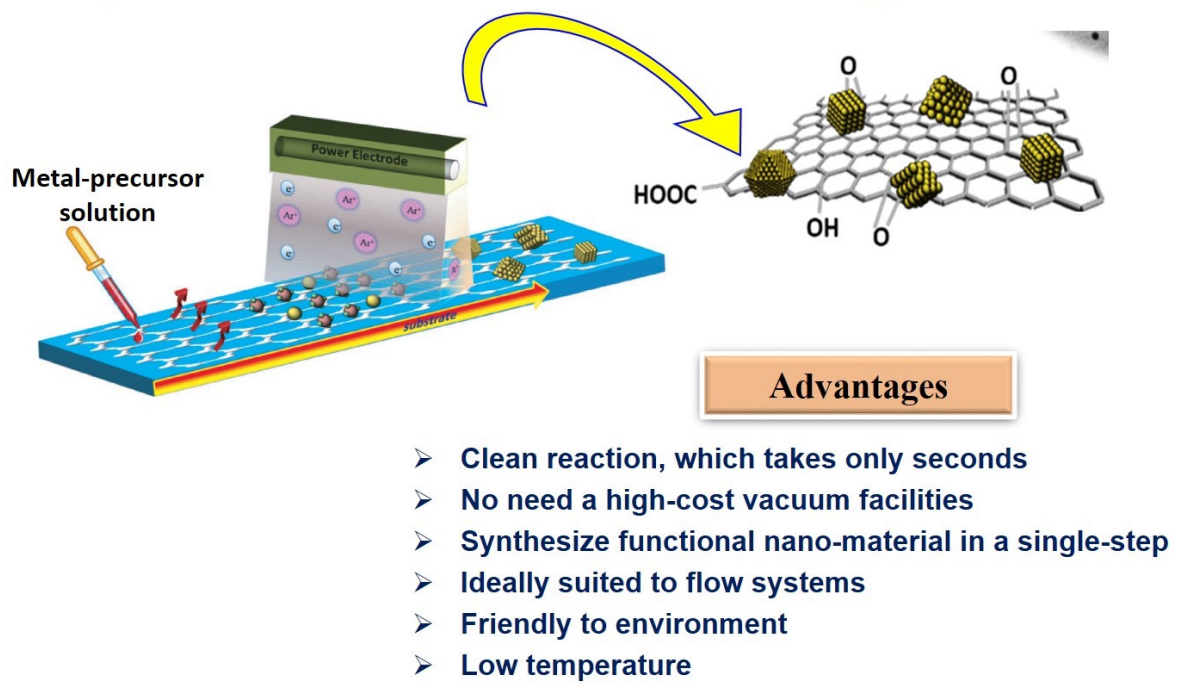

Figure 4: Dry plasma reduction technology.

Table 1: Plenary talks for SPMS2019

$\begin{array}{ll}\text { Plenary talks } & \text { Title } \\ \begin{array}{l}\text { Wiesław Stręk } \\ \text { (Polish Academy of Sciences, Poland) }\end{array} & \text { Graphene for photonics and lighting } \\ \begin{array}{l}\text { Phong D. Tran } \\ \text { (University of Science and Technology of Hanoi, Vietnam) }\end{array} & \begin{array}{l}\text { Toward construction of a viable artificial leaf for solar } \\ \mathrm{H}_{2} \text { generation }\end{array} \\ \begin{array}{l}\text { Sunglae Cho } \\ \text { (University of Ulsan, Korea) }\end{array} & \begin{array}{l}\text { High quality 2D layered materials: Growth of single } \\ \text { crystal and epitaxial thin film }\end{array} \\ \text { Phan Bach Thang } & \begin{array}{l}\text { Porous materials and their applications in energy- } \\ \text { environment-catalysis-health care }\end{array} \\ \text { (Vietnam National Science in Ho Chi Minh City, Vietnam) } & \begin{array}{l}\text { All-weather harvesting energy and fresh-water via } \\ \text { solar-driven water evaporation }\end{array} \\ \text { Van-Duong Dao } & \end{array}$



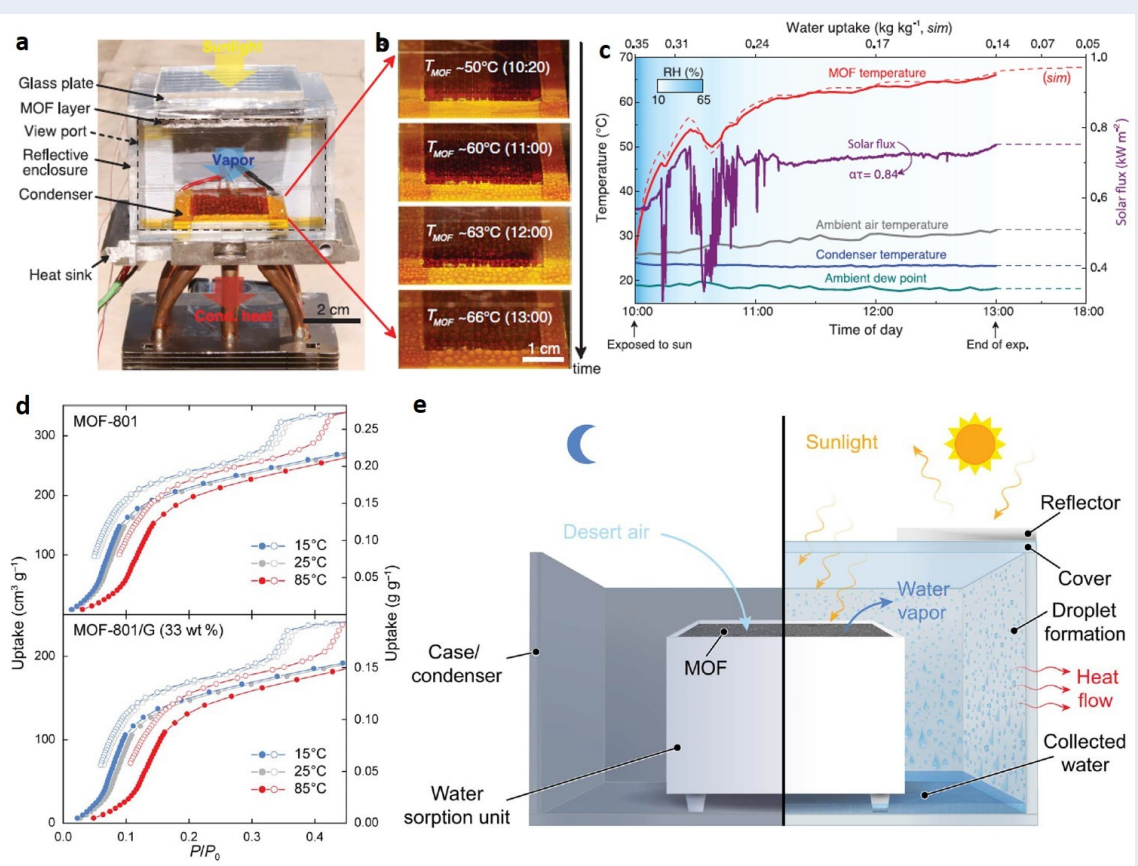

Figure 5: Proof-of-concept water-harvesting prototype ${ }^{8}$. (a) Image of a water-harvesting prototype with activated MOF-801 with a weight of $1.34 \mathrm{~g}$, a packing porosity of $\sim 0.85$, and outer dimensions of 7 by 7 by $4.5 \mathrm{~cm}$. (b) Formation and growth of droplets of water as a function of MOF temperatures (TMOF) and local time of day. (c) Representative temperature profiles for the MOF-801 layer (experimental, red solid line; predicted, red dashed line), ambient air (gray line), the condenser (blue line), and the ambient dew point(green line), as well as solar flux (purple line), as functions of time of day (14 September 2016). The background color map represents the estimated RH from the condenser saturation pressure and the layer temperature, and the upper abscissa represents the water uptake predicted from the theoretical model as afunction of time (lower abscissa). Because of losses from the absorber solarabsorptance $(a, 0.91)$ and the glass plate solar transmittance $(t, 0.92), 84 \%$ ofthe solar flux shown in (c) was used for desorption. The layer temperature and full water-harvesting potential based on complete desorption were predicted using the solar flux and environmental conditions at the end of the experiment (dashed lines). The fluctuations of the solar flux from 10:20 to 11:00 were due to the presence of clouds. Isotherms of MOF-801 and design of the MOF-based water harvester for water production fromdesert air ${ }^{9}$. (d) Water sorption isotherms (adsorption, filled symbols; desorption, open symbols) of MOF-801 and MOF-801/G at $15^{\circ} \mathrm{C}$ (blue), $25^{\circ} \mathrm{C}$ (gray), and $85^{\circ} \mathrm{C}$ (red). In comparison to previously reportedisotherms for MOF- 801, a shift of the inflection point to higher relativepressures, a lower maximum capacity, and hysteresis were observed. These findings are related to a high degree of single crystallinity of the material ${ }^{23}$. Blending MOF-801 with graphite led to a decrease of the gravimetric capacity corresponding to the added weight, while the general shape of the isotherm was fully retained. (e) Schematic of the water harvester consisting of a water sorption unit and a case. During the night, the cover of the case isopened, allowing the MOF to be saturated with moisture from desert air. Duringthe day, the case is sealed to create a closed system. Humid hot air flows fromthe MOF to the condenser and is cooled down by heat rejection to the surroundings. When the dew point is reached, condensation occurs, and liquid water collects at the bottom of the case. 
Table 2: Invited talks for SPMS2019

\begin{tabular}{l}
\hline Invited speaker \\
\hline Phuoc Huu Le \\
(Ton Duc Thang University, Viet- \\
nam) \\
Nguyen Minh Vuong \\
(Quy Nhơn University, Vietnam) \\
Nguyen Duc Anh \\
(University of Science and Technol- \\
ogy of Hanoi, Vietnam) \\
Nguyen Tuan Son \\
(University of Transport and Com- \\
munications, Vietnam) \\
Phan Thanh Hai \\
(Quy Nhơn University, Vietnam) \\
Le Thi Ly \\
(University of Science and Technol- \\
ogy of Hanoi, Vietnam) \\
Vu Ngoc Hung \\
(ITIMS, Hanoi University of Science \\
and Technology, Vietnam) \\
Pham Van Viet \\
(University of Science, VNU-HCM)
\end{tabular}

Tran Nhu Hoa

(University of Science, VNU-HCM)

Nguyen Thi Ngoc Anh

(Vietnam Academy of Science and

Technology, Vietnam)

Do Thi Kim Anh

(Vietnam National University, Vietnam)

\section{Nguyen Viet Long \\ (Saigon University, Vietnam)}

Dang Ngoc Toan

(Duy Tan University, Vietnam)

Nguyen Xuan Sang

(Saigon University, Vietnam)

\section{Title}

Magnetotransport properties of bismuth chalcogenide topological insulators: a review

$\mathrm{Pt} / \mathrm{ZnO}$ hierarchical nanostructures as efficient sensing materials for methanol sensors.

The durability enhancement of amorphous molybdenum sulfide toward proton reduction reaction in the presence of poly $(3,4$ - ethylene dioxythiophene).

Fabrication of micro supercapacitor electrodes on the flexible substrate by direct laser writing technique.

Covalent modification of graphene and graphite using diazonium chemistry

Simple synthesis nanotube $\mathrm{Cu}_{2} \mathrm{MoS}_{4}$ for both hydrogen evolution reaction and magnesium-ion batteries

Relaxor ferroelectric PLZT thin films fabricated by sol-gel technique for pulsed-power energy storage applications.

Activation Peroxymonosulfate by visible-light over $\mathrm{Ag} / \mathrm{ZnO}$ heterojunction

(Hoạt hoá Peroxymonosulfate bởi ánh sáng khả kiến sử dụng vật liệu nano cấu trúc dị thể $\mathrm{Ag} / \mathrm{ZnO}$ )

A high sensitivity optical fiber sensor for determination of heavy metals $(\mathrm{Cu}, \mathrm{Pb}, \mathrm{Cd}, \mathrm{Mn} . .$.$) in water pollutants$

(Cảm biến quang học có độ nhạy cao xác định hàm lượng kim loại nặng $(\mathrm{Cu}, \mathrm{Pb}, \mathrm{Cd}, \mathrm{Mn}$...) trong nước uống, nước ô nhiễm.)

Study the magnetic anisotropy and the dependence of the translation field perpendicular to the multilayer thin film

(Nghiên cứu tính dị hướng từ và sự phụ thuộc của trường trao đổi dịch theo phương vuông góc của màng mỏng đa lớp)

Effect of residual La on crystal structure and magnetic properties in $\mathrm{La}_{x} \mathrm{Fe}_{11.05} \mathrm{Si}_{1.95}$

(Ảnh hưởng của sự dư La lên cấu trúc tinh thể và tính chất từ trong hợp chất $\mathrm{La}_{x} \mathrm{Fe}_{11.05} \mathrm{Si}_{1.95}$ )

Synthesis, structure, and properties of gold nanoparticle materials by improved Polyol method

(Tổng hợp, cấu trúc, và tính chất hệ vật liệu hạt nano vàng bằng phương pháp Polyol cải tiến)

Establishing the mechanism of formation of the magnetic order state in $\mathrm{Ca}_{3} \mathrm{Co}_{2} \mathrm{O}_{6}$ material.

(Thiết lập cơ chế hình thành của trạng thái trật tự từ trong vật liệu $\mathrm{Ca}_{3} \mathrm{CO}_{2} \mathrm{O}_{6}$ )

Optical and photocatalyst properties of $\mathrm{TiO} 2$ and graphene nanotube combination with heat treatment.

(Tính chất quang và quang xúc tác của tổ hợp ống nano $\mathrm{TiO}_{2}$ và graphene có xử lý nhiệt) 
Table 2 continued

Tran Dang Thanh

(Vietnam Academy of Science and

Technology, Vietnam)

Nguyen Thanh Binh

(Vietnam Academy of Science and

Technology, Vietnam)
Structure and magnetic properties of crystalline nanomaterials $\mathrm{Pr}_{0.5} \mathrm{Sr}_{0.5} \mathrm{MnO}_{3}$

(Cấu trúc và tính chất từ của vật liệu nano tinh thể $\left.\operatorname{Pr}_{0.5} \mathrm{Sr}_{0.5} \mathrm{MnO}_{3}\right)$

Using fluorescence resonance energy transmission method to detect Aflatoxin

(Sử dụng phương pháp truyền năng lượng cộng hưởng huỳnh quang phát hiện Aflatoxin) 


\section{COMPETING INTERESTS}

The author(s) declare that they have no competing interests.

\section{ACKNOWLEDGMENT}

This research is funded by Vietnam National Foundation for Science and Technology Development (NAFOSTED) under grant number 103.02-2018.27.

\section{REFERENCES}

1. Strek W, Tomala R, Lukaszewicz M, Cichy B, Gerasymchuk $Y$, Gluchowski $P$, et al. Laser-induced white lighting of graphene foam. Sci Rep. 2017;7:41281. Available from: https://doi.org/ 10.1038/srep41281PMid:28112254.

2. Strek W, Cichy B, Radosinski L, Gluchowski P, Marciniak L, Lukaszewicz M, et al. Laser-induced white-light emission from graphene ceramics-opening a band gap in graphene. Light Sci Appl. 2015;4:e237. Available from: https://doi.org/10.1038/ lsa.2015.10.

3. Dao VD, Vu NH, Yun S. Recent advances and challenges for solar-driven water evaporation system toward applications. Nano Energy. 2020;68:104324. Available from: https://doi.org/ 10.1016/j.nanoen.2019.104324.

4. Dao VD, Vu NH, Choi HS. All day Limnobium laevigatum integrated nanogenerator self-driven via water evaporation. J Power Sources. 2020;448:227388. Available from: https://doi. org/10.1016/j.jpowsour.2019.227388.

5. Dao VD, Tran CQ, Ko SH, Choi HS. Dry plasma reduction to synthesize supported platinum nanoparticles for flexible dyesensitized solar cells. J Mater Chem A. 2013;1:4436. Available from: https://doi.org/10.1039/c3ta10319f.

6. Dao VD, Nang LV, Kim ET, Lee JK, Choi HS. Pt nanoparticles immobilized on CVD-grown graphene as a transparent counter electrode material for dye-sensitized solar cells. ChemSusChem. 2013;6:1316. PMID: 23828826. Available from: https://doi.org/10.1002/cssc.201300353.

7. Trung TN, Kim D, Lee JH, Dao VD, Choi HS, Kim ET. Simple and reliable lift-off patterning approach for graphene and graphene-Ag nanowire hybrid films. ACS Appl Mater Interfaces. 2017;9:21406-21412. PMID: 28573859. Available from: https://doi.org/10.1021/acsami.7b05790.

8. Kim H, Yang S, Rao SR, Narayanan S, Kapustin EA, Furukawa $\mathrm{H}$, et al. Water harvesting from air with metal-organic frameworks powered by natural sunlight. Science. 2017;356:430434. PMID: 28408720. Available from: https://doi.org/10.1126/ science.aam8743.

9. Fathieh F, Kalmutzki MJ, Kapustin EA, Waller PJ, Yang J, Yaghi OM. Practical water production from desert air. Sci Adv. 2018;4:eaat3198. PMID: 29888332. Available from: https: //doi.org/10.1126/sciadv.aat3198.

10. Doan TLH, Nguyen HL, Pham HQ, Pham-Tran NN, Le TN, Cordova KE. Tailoring the optical absorption of water-stable ZrIV- and HfIV-based metal-organic framework photocatalysts. Chem Asian J. 2015;10:2660. PMID: 26257077. Available from: https://doi.org/10.1002/asia.201500641.

11. Choi KM, Jeong HM, Park JH, Zhang YB, Kang JK, Yaghi OM. Supercapacitors of nanocrystalline metal-organic frameworks. ACS Nano. 2014;8:7451. PMID: 24999543. Available from: https://doi.org/10.1021/nn5027092.

12. Tu TN, Phan NQ, Vu TT, Nguyen HL, Cordova KE, Furukawa H. High proton conductivity at low relative humidity in an anionic Fe-based metal-organic framework. J Mater
Chem A. 2016;4:3638. Available from: https://doi.org/10.1039/ C5TA10467J.

13. Nguyen MV, Lo THN, Luu LC, Nguyen HTT, Vu TN. Enhancing proton conductivity in a metal-organic framework at $\mathrm{T}>80^{\circ} \mathrm{C}$ by an anchoring strategy. J Mater Chem A. 2018;6:1816. Available from: https://doi.org/10.1039/C7TA10148A.

14. Nguyen PTK, Nguyen HTD, Nguyen HN, Trickett CA, Ton QT, Gutiérrez-Puebla E, et al. New metal-organic frameworks for chemical fixation of CO2. ACS Appl Mater \& Inter. 2018;10:733. Available from: https://doi.org/10.1021/acsami.7b16163PMid: 29251904.

15. Nguyen HTD, Tran YBN, Nguyen HN, Nguyen TC, Gandara F, Nguyen PTK. A series of metal-organic frameworks for selective $\mathrm{CO} 2$ capture and catalytic oxidative carboxylation of olefins. Inorg Chem. 2018;57:13772. PMID: 30299917. Available from: https://doi.org/10.1021/acs.inorgchem.8b02293.

16. Nguyen LHT, Nguyen TT, Nguyen HL, Doan TLH, Tran PH. A new superacid hafnium-based metal-organic framework as a highly active heterogeneous catalyst for the synthesis of benzoxazoles under solvent-free conditions. Catal Sci Technol. 2017;7:4346. Available from: https://doi.org/10.1039/ C7CY01668A.

17. Vu BT, Shahin SA, Croissant J, Fatieiev $Y$, Matsumoto K, Doan $\mathrm{TLH}$, et al. Chick chorioallantoic membrane assay as an in vivo model to study the effect of nanoparticle-based anticancer drugs in ovarian cancer. Sci Rep. 2018;8:8524. PMID: 29867159. Available from: https://doi.org/10.1038/s41598018-25573-8.

18. Tran PD, Thu TV, Orio M, Torelli S, Truong QD, Nayuki K, et al. Coordination polymer structure and revisited hydrogen evolution catalytic mechanism for amorphous molybdenum sulfide. Nature Materials. 2016;15:640-646. PMID: 26974410. Available from: https://doi.org/10.1038/nmat4588.

19. Nguyen QT, Nguyen PD, Nguyen DN, Truong QD, Chi TTK, Ung TTD, et al. Novel amorphous molybdenum selenide as an efficient catalyst for hydrogen evolution reaction. ACS Appl Mater Interfaces. 2018;10:8659-8665. PMID: 29424526. Available from: https://doi.org/10.1021/acsami.7b18675.

20. Tran TD, Nguyen MTT, Le HV, Nguyen DA, Truong QD, Tran PD. Gold nanoparticles as an outstanding catalyst for the hydrogen evolution reaction. Chem Commun. 2018;54:33633366. PMID: 29542767. Available from: https://doi.org/10. 1039/C8CC00038G.

21. Nguyen LN, Thuy UTD, Truong QD, Honma I, Nguyen QL, Tran PD. Electrodeposited amorphous tungsten-doped cobalt oxide as an efficient catalyst for the oxygen evolution reaction. Chemistry - An Asian Journal. 2018;13:1530-1534. PMID: 29708656. Available from: https://doi.org/10.1002/asia. 201800401.

22. Duong TM, Nguyen PD, Nguyen AD, Le LT, Nguyen LT, Pham $\mathrm{HV}$, et al. Insights into the electrochemical polymerization of [Mo3S13]2- generating amorphous molybdenum sulfide. Chemistry-A European Journal. 2019;25:13676-13682. PMID: 31403722. Available from: https://doi.org/10.1002/ chem.201903098.

23. Le HV, Tran PD, Mai HV, Ung TTD, Nguyen LQ. Gold protective layer decoration and pn homojunction creation as novel strategies to improve photocatalytic activity and stability of the H2-evolving copper (I) oxide photocathode. Int J Hydrogen Energy. 2018;43:21209-21218. Available from: https: //doi.org/10.1016/j.ijhydene.2018.09.192.

24. Le HV, Tran PD, Chang JS, Ung TTD, Nguyen LQ. Hybrid amorphous MoSx-graphene protected $\mathrm{Cu} 2 \mathrm{O}$ photocathode for better performance in $\mathrm{H} 2$ evolution. Int J Hydrogen Energy. 2019;44:14635-14641. Available from: https://doi.org/ 10.1016/j.ijhydene.2019.04.129. 